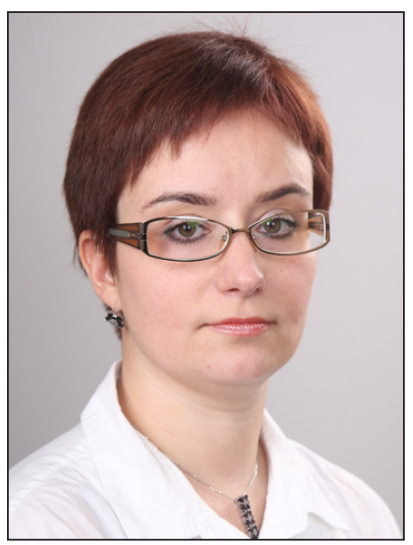

Сакара Наталія Юріївна,

кандидат юридичних наук, дочент, дочент кафедри цивільного процесу, Начіональний юридичний університет імені Ярослава Мудрого, Україна, м. Харків e-mail: Natalija_sakara@mail.ru ORCID 0000-0001-8501-3756

\title{
YAK 347.921.6
}

\section{ПРО ПРАВОВУ ПРИРОАУ СУАОВОГО ЗБОРУ}

Стаття присвячена дослідженню правової природи судового збору. Враховуючи функції, які він виконує, пропонується розуміти під ним платіж до бюджету, що здійснюється на виконання специфічних публічно-правового та процесуального зобов'язань, у зв'язку з реалізачією особою права на звернення до суду за судовим захистом або з ухваленням щодо такої особи рішення, передбаченого Законом України «Про судовий збір». Сплата судового збору має тягнути за собою здійснення правосуддя з метою захисту прав, свобод чи інтересів його платника.

Ключові слова: судові витрати; державне мито, судовий збір; функції судового збору; публічно-правове зобов’язання; процесуальне зобов'язання.

Cакара Н. Ю., кандидат юридических наук, доцент, доцент кафедры гражданского процесса, Национальный юридический университет имени Ярослава Мудрого, Украина, г. Харьков.

e-mail: Natalija_sakara@mail.ru ; ORCID 0000-0001-8501-3756

О правовой природе судебного сбора

Статья посвящена исследованию правовой природы судебного сбора. Учитывая функиии, которые он выполняет, автор предлагает под ним понимать платеж в бюджет, осуществляемый для выполнения специфических публично-правового и процессуального обязательств, в связи с реализащией лицом права на обращения в суд за судебной защитой или с вынесением в отношении такого лища решения, предусмотренного Законом Украинь «О судебном сборе». Уплата судебного сбора влечет за собой осуществление правосудия с иелью защить прав, свобод и интересов его плательщика.

Ключевые слова: судебные расходы; государственная пошлина; судебный сбор; функции судебного сбора; публично-правовое обязательство; процессуальное обязательство.

Постановка проблеми. Однією з умов реалізації особою права на звернення до суду за судовим захистом була й залишається сплата певної грошової суми, що зараховується до державного бюджету і включається до складу судових витрат. Відповідно до ч. 1 ст. 63 ЦПК 1963 р. вона мала назву «дер- 
жавне мито» й сплачувалася відповідно до Декрету Кабінету Міністрів України «Про державне мито» від 21.01.1993 р. № 7-93 (далі - Декрет КМУ) [1] 3 подальшими змінами та доповненнями. Частина 1 ст. 79 Цивільного процесуального кодексу 2004 р. (далі - ЦПК) передбачила, що судові витрати складаються 3 «судового збору», а не 3 «державного мита», однак при цьому ч. 5 Розділу XI «Прикінцеві та перехідні положення» було встановлено, що до набрання чинності законом, який регулює порядок сплати й розміри судового збору, останній при зверненні до суду сплачується у порядку і розмірах, встановлених законодавством для державного мита. У зв'язку з наведеним виникає питання, чи можна вважати «судовий збір» та «державне мито» тотожними поняттями, які використовуються законодавцем як синоніми, чи зі зміною назви платежу відбулася й зміна його правової природи.

Пошук відповіді на зазначене вище питання є дуже важливим, оскільки розуміння змісту юридичної категорії, що застосовується, та правильність у використанні терміну її позначення відіграють важливу роль як у забезпеченні правової визначеності як одного з атрибутів права, так і в дотриманні принципу верховенства права. Тому процесу впровадження нового правового явища в правову реальність має передувати осмислення його природи, тобто сукупності властивостей, що визначають його специфічність і відмінність від інших правових явищ, визначення місця серед інших правових явищ. Хибне уявлення про сутність будь-якої правової категорії, викликане його невизначеністю, може потягнути за собою помилку як в процесі іiї використання, так і при спробі передбачити наслідки такої поведінки.

Вважаємо, що осмислення правової природи судового збору слід розпочинати зі з'ясування сутності судових витрат взагалі, оскільки категорії судові витрати та судовий збір співвідносяться між собою як ціле та частина. При цьому, як відомо, частина завжди переймає окремі властивості цілого та внутрішньо погоджується з іншими частинами, хоча й зберігає свою специфічність. Тому розкриття змісту категорії судові витрати надасть можливість виявити ознаки, які, в тому числі, можуть бути притаманні й судовому збору.

Аналіз літературних даних. У науці цивільного процесуального права інститут судових витрат досліджується впродовж тривалого часу. Так, на нього звертали увагу у своїх працях дореволюційні вчені-процесуалісти $Є$. Нефедьєв, Є. Васьковський, Т. Яблочков, К. Малишев, К. Победоносцев та ін. За радянських часів його вивченням займалися А. Бонер, М. Бородін, М. Вікут, М. Гукасян, М. Гурвіч, А. Добровольський, А. Клейман, Н. Чечина, Д. Чечот, М. Шакарян, К. Юдельсон та ін. На сучасному етапі розвитку науки цивільного процесуального права увага до даного інституту значно зросла, оскільки можливість реалізації особою права на звернення до суду за судовим захистом, тобто доступ до правосуддя безпосередньо залежить від фінансової спроможності сплатити судові витрати. При цьому, враховуючи потреби сучасності, низка вчених (Ю. Білоусов, А. Власов, І. Приходько, П. Шевчук та ін.) аналізують даний інститут в контексті доступності правосуддя, відстоюючи або 
необхідність введення безкоштовного правосуддя, або встановлення належного (низького) розміру судових витрат. Окремі процесуалісти (С. Богля, М. Вафін, Л. Глущенко, Т. Сгорова, С. Шокуєва та ін.) зосереджують свою увагу на з’ясуванні сутності даного явища.

Незважаючи на проведені чисельні дослідження судових витрат, питання визначення сутності судового збору, за загальним правилом, не розглядалося. Це обумовлено, по-перше, тим, що термін «судовий збір» нещодавно з'явився в національному законодавстві лише з прийняттям ЦПК, розміри та порядок його сплати були врегульовані Законом України «Про судовий збір» від 08.07.2011 р. № 3674-VI (далі - 3У «Про судовий збір») [2]. По-друге, враховуючи положення ч. 1 ст. 79, ч. 5 Розділу XI «Прикінцеві та перехідні положення» ЦПК, судовий збір апріорі вважається наступником державного мита безвідносно його специфіки, тобто наявність відмінностей між цими платежами просто не розглядається (О. Зварич, О. Штефан). По-третє, основна увага в літературі приділяється не природі цього явища, а розміру, порядку сплати та звільненню від його сплати, оскільки це безпосередньо впливає, як вже зазначалося, на можливість звернення особи до суду за судовим захистом.

Mema cmammi - з'ясувати на підставі проведеного дослідження інституту судових витрат, державного мита правової природи судового збору як різновиду судових витрат.

У науці цивільного процесуального права даються різні визначення поняттю «судові витрати». Так, дехто з учених під судовими витратами розуміють витрати, які несуть особи, які беруть участь у розгляді справи, у зв’язку з розглядом та вирішенням цивільної справи [3, с. 178; 4, с. 158; 5, с. 140-141]. Інші вчені судовими витратами називають витрати держави на здійснення правосуддя [6, с. 14], що покладаються законом на сторони, треті особи із самостійними вимогами і заявників у справах окремого провадження з метою їх часткової компенсації [7, с. 3], спонукання до добровільного виконання обов’язків та попередження необгрунтованих звернень до суду [8, с. 141-142]. I. B. Решетнікова зазначає, що їх можна розглядати як грошову суму, що сплачується вказаними в Законі особами у зв'язку з провадженням у цивільній справі в суді [9, с. 193]. О. М. Шокуєва пропонує під судовими витратами у цивільному судочинстві розуміти затрати, покладені на бюджет, а також на осіб, які беруть участь у справі, з приводу і у зв’язку з розглядом і вирішенням цивільної справи в суді загальної юрисдикції і мировими суддями з метою компенсації затрат на правосуддя і попередження необгрунтованих звернень до суду $[6$, с. 8, 14]. Ю. Ф. Беспалов і О. Ю. Беспалов пропонують під судовими витратами в цивільному судочинстві розуміти кошти у вигляді збору в дохід держави, сплаченого сторонами за здійснення щодо них судом юридично значущих дій у порядку, передбаченому законодавством про податки та збори, та грошові кошти, сплачені учасниками цивільного судочинства у зв’язку з їх участю в розгляді справи, виконанні рішення суду або отриманні доказів у справі, що відшкодовуються за рахунок коштів учасників процесу 
або держави у порядку та розмірі, передбаченому цивільним процесуальним законодавством [10, с. 8]. Крім того, в науці виділяють такі функції інституту судових витрат: матеріальне забезпечення цивільного судочинства шляхом часткового залучення фінансових коштів осіб, які беруть участь у справі; відшкодування витрат, пов'язаних з розглядом справи, учасникам процесу; вплив на процесуальну поведінку учасників процесу; запобігання неправомірній та недобросовісній процесуальній поведінці (зловживання процесом) та покарання за вказані дії [6, с. 8, 14; 7, с. 9; 11, с. 303].

Слід зазначити, що не з усіма наведеними вище положеннями можна погодитися, тому вони потребують певного уточнення. Так, по-перше, що стосується суб'єктів, які мають нести судові витрати. Визначення, які передбачають, що судові витрати - це або витрати осіб, які беруть участь у розгляді справи, або витрати держави, є неповними. За загальним правилом судові витрати покладаються на осіб, які беруть участь у розгляді справи (мова йде про сторін та третіх осіб, які заявляють самостійні вимоги на предмет спору). Кошти, які витрачає держава на фінансування органів судової влади, тобто на виконання обов'язку, передбаченого Конституцією України, до поняття судових витрат не включаються. Як виключення, лише у випадках, коли обидві сторони звільнені від сплати судових витрат, вони компенсуються за рахунок держави. Натомість визначення, в якому вказується, що судові витрати $є$ витратами учасників цивільного судочинства у зв'язку з їх участю в розгляді справи, необгрунтовано розширюють склад суб'єктів, які повинні нести судові витрати. Так, до учасників цивільного процесу (Глава 4 Розділу 1 ЦПК) відносяться як особи, які беруть участь у справі (ст. 26 ЦПК), так і інші учасники (ст. 47 ЦПК). Однак остання група суб’єктів, тобто секретар судового засідання, судовий розпорядник, свідок, експерт, перекладач, спеціаліст, особа, яка надає правову допомогу, ніякі судові витрати у зв'язку зі своєю участю у справі не несуть. Навпаки, відповідно до ч. 3 ст. 79, ст. 88 ЦПК витрати, пов’язані із залученням свідків, спеціалістів, перекладачів та проведенням судових експертиз, витрати, пов'язані з проведенням огляду доказів за місцем їх знаходження та вчинення інших дій, необхідних для розгляду справи, несуть сторони.

По-друге, не відповідають дійсності й визначення, що судові витрати є затратами держави на здійснення правосуддя, оскільки до складу судових витрат входять як судовий збір, так і витрати, пов'язані з розглядом справи, тобто витрати на правову допомогу, витрати сторін, їх представників, що пов'язані з явкою до суду, витрати, пов'язані із залученням свідків, експертів, перекладачів та проведенням судових експертиз, витрати, пов'язані 3 проведенням огляду за місцем їх знаходження та вчинення інших дій, необхідних для розгляду справи; витрати, пов'язані з публікацією в пресі оголошення про виклик відповідача.

По-третє, важко погодитися з виділенням такої функції судових витрат як матеріальне забезпечення цивільного судочинства шляхом часткового залучення фінансових коштів осіб, які беруть участь у справі, оскільки від- 
повідно до ч. 1 ст. 130 Конституції України держава забезпечує фінансування та належні умови функціонування і діяльності суддів, які здійснюють правосуддя, тобто вона не може перекладати навіть частково та опосередковано виконання своїх обов'язків на інших осіб. Наведені положення передбачені також як у Законі України «Про судоустрій та статус суддів» у редакції Закону України «Про забезпечення права на справедливий суд» [12], так і в Бюджетному кодексі [13]. Так, ч. 4 ст. 17, ст. 145 даного Закону закріплюють, що фінансування всіх судів в Україні здійснюється виключно за рахунок коштів Державного бюджету України. Видатки загального фонду Державного бюджету України на утримання судів належать до захищених статей видатків Державного бюджету України. Згідно 3 п. 1 ч. 1 ст. 82, п. 2 ч. 1 ст. 87 Бюджетного кодексу України видатки на забезпечення незалежного судочинства, судову владу виконуються лише за рахунок коштів державного бюджету і не можуть фінансуватися з місцевих бюджетів.

По-четверте, вважаємо, що такі функції як вплив на процесуальну поведінку учасників процесу та запобігання неправомірній та недобросовісній процесуальній поведінці (зловживання процесом) та покарання за вказані дії $є$ тотожними по суті, оскільки переслідують одну мету - утримання сторін та інших осіб, які беруть участь у справі, від недобросовісної поведінки, тому їх недоцільно розмежовувати.

Найбільш слушне визначення, на наш погляд, міститься в п. 1 Постанови Пленуму Вищого спеціалізованого суду України з розгляду цивільних і кримінальних справ «Про застосування судами законодавства про судові витрати у цивільних справах» від 17.10.2014 р. № 10 [14]. Так, під судовими витратами пропонується розуміти передбачені законом витрати (грошові кошти) сторін, інших осіб, які беруть участь у справі, понесені ними у зв’язку з ії розглядом та вирішенням, а у випадках їх звільнення від сплати - це витрати держави, які вона несе у зв'язку з вирішенням конкретної справи. Вбачається, що вони виконують дві основні функції. Першою є відшкодування учасникам процесу витрат, пов'язаних з розглядом справи: оплатою правової допомоги, відшкодуванням сторонам, їх представникам, свідкам, спеціалістам, перекладачам, експертам витрат, пов’язаних з переїздом до іншого населеного пункту, найманням житла, виплатою добових (у разі переїзду до іншого населеного пункту), компенсацією за втрачений заробіток чи відрив від звичайних занять, витрат, пов'язані з публікацією в пресі оголошення про виклик відповідача. Реалізуючи другу функцію, вони служать певним важелем для здійснення впливу на поведінку учасників процесу та запобігання неправомірної та недобросовісної процесуальної поведінки, тобто є фактором, що певною мірою дисциплінує сторін та інших осіб, які беруть участь у справі.

Оскільки судовий збір є частиною судових витрат, то наведене визначення можна поширити й на нього, однак його слід уточнити з урахуванням особливостей, притаманних даному платежу як частки цілого. Їх виділення доцільно проводити одночасно зі з'ясуванням можливої тотожності категорій державного мита та судового збору. 
Відповідно до ст. 1 ЗУ «Про судовий збір» під останнім розуміється збір, що справляється на всій території України за подання заяв, скарг до суду, за видачу судами документів, а також у разі ухвалення окремих судових рішень, передбачених цим Законом. Судовий збір стягується на всій території України з громадян України, іноземців, осіб без громадянства, підприємств, установ, організацій, інших юридичних осіб (у тому числі іноземні) та фізичних осіб - підприємців, які звертаються до суду чи стосовно яких ухвалене судове рішення, передбачене цим Законом (ст. 2). Він справляється за подання до суду позовної заяви та іншої заяви, передбаченої процесуальним законодавством; за подання до суду апеляційної і касаційної скарг на судові рішення, заяви про перегляд судового рішення у зв'язку з знову виявленими обставинами, заяви про скасування рішення третейського суду, заяви про видачу виконавчого документа на примусове виконання рішення третейського суду та заяви про перегляд судових рішень Верховним Судом України; за видачу судами документів; у разі ухвалення судового рішення, передбаченого цим Законом (ст. 3). 3 наведених положень Закону випливає, що судовий збір сплачується лише у зв'язку зі зверненням особи до суду, вчиненням окремих процесуальних дій під час розгляду справи у суді, видачею судових документів, тобто його сплата пов’язана суто з процесуальною діяльністю сторін та інших осіб, які беруть участь у справі, тобто з діяльністю, врегульованою процесуальним законодавством.

Стаття 1 Декрету КМУ встановлює, що його платниками на території України є фізичні та юридичні особи за вчинення в їхніх інтересах дій та видачу документів, що мають юридичне значення, уповноваженими на те органами. Стаття 2 (в редакції, чинній до введення в дію ЗУ «Про судовий збір») передбачала, що державне мито справляється із позовних заяв, заяв $з$ переддоговірних спорів, заяв (скарг) у справах окремого провадження і скарг на рішення, прийняті відносно релігійних організацій, з апеляційних скарг на рішення судів і скарг на рішення, що набрали законної сили, а також за видачу судами копій документів; із позовних заяв і заяв кредиторів у справах про банкрутство, що подаються до господарських судів, та апеляційних і касаційних скарг на рішення та постанови, а також заяв про їх перегляд за знову виявленими обставинами; за вчинення нотаріальних дій державними нотаріальними конторами і виконавчими комітетами сільських, селищних, міських Рад народних депутатів, а також за видачу дублікатів нотаріально засвідчених документів; за державну реєстрацію актів цивільного стану, а також повторну видачу громадянам свідоцтв про реєстрацію актів цивільного стану та свідоцтв у зв'язку зі зміною і поновленням актових записів цивільного стану тощо. Наведені вище положення дають можливість зробити висновок, що, по-перше, сфера застосування державного мита була дещо ширшою, оскільки воно сплачувалося як у зв’язку з процесуальною, так і непроцесуальною діяльністю. По-друге, сплата державного мита передбачала вчинення в інтересах платника дій та видачу документів, тобто розглядалася як плата 
за послуги. Після прийняття ЗУ «Про судовий збір» були внесені зміни до ст. 2 Декрету КМУ, відповідно до яких державне мито продовжує сплачуватися, але лише при зверненні лише до несудових органів у випадках, встановлених у Декреті КМУ, тобто при вчиненні непроцесуальної діяльності.

Частина 1 ст. 14 Закону України «Про систему оподаткування» від 25.06.1991 р. № 1251-XII р в редакції Закону України «Про внесення змін до деяких законодавчих актів України щодо професійної і трудової реабілітації інвалідів» від 06.10.2005 р. № 2960- IV [15] до загальнодержавних податків та зборів відносив як державне мито (п. 6), так і судовий збір (п. 27). Наведене свідчить, що починаючи з 01.01.2006 р. вищезазначені категорії мають застосовуватися як рівнопорядкові, тобто судовий збір не виступає видом (частиною) державного мита, як це продовжують стверджувати окремі науковці [16, с. 7; 17]. Цей висновок підтверджується також і тим, що, як вже зазначалося вище, сфери використання цих платежів чітко визначені та не мають «точки перетину». Так, судовий збір сплачується лише при зверненні до судових органів, а державне мито - до несудових.

Вбачається, що закріплення в ст. 79 ЦПК 2004 р. поняття судовий збір потягло за собою не просто зміну назви платежу, але й приведення її у відповідність 3 його сутністю. Так, як вже зазначалося, державне мито було та залишається платою за певні послуги. Оскільки воно сплачувалося при зверненні до суду, то правосуддя можна було розглядати в якості послуги. До речі, такі пропозиції містилися в проекті Концепції розвитку правосуддя в Україні [18, с. 245] та були закріплені в Концепції вдосконалення судівництва для утвердження справедливого суду в Україні відповідно до європейських стандартів, схваленої Указом Президента України від 10.05.2006 р. № 361/2006 [19]. Однак, як уже зазначалося, таке визначення правосуддя є неприпустимим. Якщо останнє - це послуга, то сторона, яка звертається за захистом до суду, може визначати порядок та умови надання цієї послуги, впливати на результати розгляду справи, що робить суд підпорядкованим волі сторони. Таке розуміння суперечить сутності правосуддя і призводить, по суті, до визнання презумпції фінансової залежності судового органу від особи, яка оплачує його послуги, що суперечить п. 1 ст. 6 Конвенції про захист прав людини та основоположних свобод і Конституції України, які, навпаки, проголошують незалежність та недоторканість суддів та підкорення їх лише законові (ст. 126 Конституції України) [20, с. 64, 204].

Як вже зазначалося, в п. 27 ч. 1 ст. 14 Закону України «Про систему оподаткування» від 25.06.1991 р. № 1251-XII в редакції Закону України «Про внесення змін до деяких законодавчих актів України щодо професійної і трудової реабілітації інвалідів» від 06.10.2005 р. № 2960- IV, який втратив чинності з 01.01.2011 р., судовий збір розглядався як загальнодержавний збір. Однак прийнятий Верховною Радою України Податковий кодекс України [21] серед переліку загальнодержавних та місцевих податків та зборів (статті 9,10$)$ не закріплює його та взагалі ніяким чином не визначає його місце серед обов'язкових платежів. 
Вбачається, що при визначенні правової природи судового збору необхідно виходити з тих функцій, які він виконує.

По-перше, за рахунок судового збору відбувається наповнення спеціального фонду Державного бюджету. Так, відповідно до ст. 9 Закону України «Про судовий збір» судовий збір сплачується за місцем розгляду справи та зараховується до спеціального фонду Державного бюджету України. Кошти судового збору спрямовуються на забезпечення здійснення правосуддя, зміцнення матеріально-технічної бази судів, включаючи створення та забезпечення функціонування Єдиної судової інформаційної системи, веб-порталу судової влади, комп'ютерних локальних мереж, сучасних систем фіксування судового процесу, придбання та обслуговування комп'ютерної і копіювально-розмножувальної техніки, впровадження електронного цифрового підпису. Таким чином, можна дійти висновку, що, сплачуючи судовий збір, особа виконує певне публічно-правове зобов'язання, яке покладається на неї державою та не залежить від іiі розсуду, тобто судовий збір носить публічно-правовий характер.

До речі, таке розуміння природи платежу, що сплачується при зверненні до суду або у зв'язку з ним є достатньо поширеним. Так, Європейський суд з прав людини в своїх рішеннях виходить з того, що судові витрати (costs of court proceedings) мають розглядатися в якості «зборів» (contributions) в розумінні ст. 1 Протоколу 1. При цьому відповідно до § 2 даної статті держава має право вводити в дію такі закони, які, на їі думку, є необхідними для забезпечення сплати податків чи інших зборів або штрафів [22]. Аналогічна позиція закріплена, наприклад, і в законодавстві Португалії. При цьому, Верховний суд цієї країни прирівнює обов'язок для сторін сплатити судові витрати до обов'язку платників податків сплатити податки. Він виходить з того, що держава як активний суб'єкт фіскального зобов'язання має право стягувати грошові збори, натомість вона має надати особам (пасивним суб'єктам) доступ до судової служби [23].

У зв'язку з наведеним вважаємо за можливе при визначенні природи судового збору в деякій мірі застосувати за аналогією п. 6.2 ст. 6 Податкового кодексу України, який містить визначення поняття «збір» [24, 443]. Так, збором (платою, внеском) є обов’язковий платіж до відповідного бюджету, що справляється з платників зборів, з умовою отримання ними спеціальної вигоди, у тому числі внаслідок вчинення на користь таких осіб державними органами, органами місцевого самоврядування, іншими уповноваженими органами та особами юридично значимих дій. Такою спеціальною вигодою є сукупність процесуальних дій, що виконуються суддею (судом) на вимогу такої особи: розгляд позовної заяви, заяви, скарги по суті та винесення за результатами цього відповідних судових рішень. У загальному вигляді мова йде про те, що, сплативши судовий збір, його платник отримує доступ до правосуддя, тобто він має можливість передати вирішення спору про право спеціально уповноваженому на це органу - суду, отримати «підтримку» від останнього при вчиненні окремих процесуальних дій, а не займатися цим самотужки. Наведене, однак, зовсім не означає, що суд зобов’язаний діяти виключно в інтересах такої особи. 
По-друге, необхідність сплати судового збору, як і всіх інших судових витрат, дає можливість запобігти неправомірній та недобросовісній процесуальній поведінці (зловживання процесом), стимулює сторони врегулювати свій спір у позасудовому порядку. Так, відповідно до ч. 1 ст. 88 ЦПК стороні, на користь якої ухвалено рішення, суд присуджує з другої сторони понесені нею і документально підтверджені судові витрати. Якщо позов задоволено частково, судові витрати присуджуються позивачеві пропорційно до розміру задоволених позовних вимог, а відповідачеві - пропорційно до тієї частини позовних вимог, у задоволенні яких позивачеві відмовлено.

Оскільки судовий збір сплачується виключно у зв'язку зі зверненням до суду або вчиненням окремих процесуальних дій (забезпечення позову, забезпечення доказів тощо), то обов'язок, що покладається на особу у зв'язку з його сплатою, необхідно вважати процесуальним. Його невиконання тягне за собою негативні процесуальні наслідки. Так, наприклад, відповідно до ч. 1 ст. 121 ЦПК суддя, встановивши, що при поданні позовної заяви не сплачено судовий збір, постановляє ухвалу про залишення заяви без руху. 3 наведеного випливає, що судовий збір носить також процесуальний характер.

Висновок. На підставі викладеного під судовим збором слід розуміти платіж до бюджету, який здійснюється на виконання специфічних публічно-правового та процесуального зобов’язань, у зв’язку з реалізацією особою права на звернення до суду за судовим захистом або у зв'язку з ухваленням щодо такої особи рішення, передбаченого Законом України «Про судовий збір», сплата якого має тягнути вчинення щодо платника певних юридично значущих дій, тобто отримання «спеціальної вигоди». При цьому, остання має проявлятися у розгляді позовної заяви, заяви, скарги по суті та винесенні за результатами цього відповідних судових рішень, тобто у здійсненні правосуддя з метою захисту прав, свобод та інтересів такої особи. Для даного платежу характерна дуалістична природа: він є як публічно-правовим, так і процесуальним платежем одночасно.

\section{Список літератури:}

1. Про державне мито : Декрет Кабінету Міністрів України від 21.01.1993 р. № 7-93 // Відом. Верхов. Ради України. - 1993. - № 13 (30.03.1993). - Ст. 113.

2. Про судовий збір : Закон України від 08.07.2011р. № 3674-VI // Офіційний вісник України. - 2011. - № 59 (12.08.2011). - Ст. 2349.

3. Советский гражданский процесс : учебник / под ред. К. И. Комиссарова и В. М. Семенова. - 2-е изд., перераб и доп. - Москва : Юрид. лит. - 480 с.

4. Гражданское процессуальное право России : учебник для вузов / под ред. М. С. Шакарян. - Москва : Юристъ, 2002. - 634 с.

5. Цивільний процесуальний кодекс України :науково-практичний коментар / за ред. В. В. Комарова. - Харків : Одіссей, 2001. - 816 с.

6. Шокуева Е. М. Институт судебных расходов в российском гражданском судопроизводстве : автореф. дис. ... канд. юрид. наук : 12.00 .15 / Е. М. Шокуева. - Саратов. гос. акад. права. Саратов, 2005. - 27 с.

7. Богля С. С. Судові втрати у цивільному судочинстві : автореф. дис. ... канд. юрид. наук : 12.00.03 / С. С. Богля ; Нац. ун-т внутр. справ МВС України - Харків, 2005. - 21 с. 
8. Советский гражданский процесс / под ред. проф. М. К. Треушникова. - Москва: Изд-во Моск. ун-та, 1989. - 463 с.

9. Гражданский процесс : учебник / отв. ред. проф. В. В. Ярков. - 5-е изд., перераб. и доп. Москва : Волтерс Клувер, 2004. - 720 с.

10. Беспалов Ю. Ф. Судебные расходы по гражданским, уголовным делам и делам об административных правонарушениях : учеб.-практ. пособие / Ю. Ф. Беспалов, А. Ю. Беспалов. Москва : Проспект, 2014. - 216 с.

11. Симайтис Р. Функции гражданско-процессуального института судебных расходов / Римантас Симайтис // Гражданский процесс: наука и преподавание / под ред. М. К. Трешникова, Е. А. Борисовой. - Москва : Изд. Дом «Городец», 2005. - С. 302-313.

12. Про забезпечення права на справедливий суд : Закон України від 12.02.2015 р. № 192VIII // Офіційний вісник України. - 2015. - № 17 (10.03.2015). - Ст. 447.

13. Бюджетний кодекс України від 08.07.2010 р. № 2456-VI // Офіційний вісник України. 2010. - № 59. - Ст. 2047.

14. Про застосування судами законодавства про судові витрати у цивільних справах [Електронний ресурс] : постанова Пленуму Вищого спеціалізованого суду України з розгляду цивільних і кримінальних справ від 17.10.2014 р. № 10. - Режим доступу : http://zakon4.rada.gov.ua/ laws/show/v0010740-14.

15. Про внесення змін до деяких законодавчих актів України щодо професійної і трудової реабілітації інвалідів : Закон України від 06.10.2005 р. № 2960- IV // Офіційний вісник України. - 2005. - № 50 (28.12.2005) - Ст. 3108.

16. Зварич О. В. Інституційні засади судового збору і державного мита / О. В. Зварич // Вісник Академії митної служби України. Серія «Економіка» / Акад. митної служби України. Дніпропетр. : Акад. митної служби України, 2013. - № 2 (50). - С. 5-10.

17. Лазюк С. В. Судовий збір як різновид державного мита / С. В. Лазюк // Право і суспільство. - 2012. - № 6. - С. 63-65.

18. Куйбіда Р. О. Реформування правосуддя в Україні: стан і перспективи : монографія / Р. О. Куйбіда. - Київ : Атіка, 2004. - 288 с.

19. Про Концепцію вдосконалення судівництва для утвердження справедливого суду в Україні відповідно до європейських стандартів : Указ Президента від 10.05.2006 р. № 361/2006 // Офіційний вісник України. - 2006. - № 19. - Ст. 1376.

20. Сакара Н. Ю. Проблема доступності правосуддя у цивільних справах : монографія / Н. Ю. Сакара. - Харків : Право, 2010. - 256 с.

21. Податковий кодекс України від 02.12.2010 р. № 2755-VI // Офіційний вісник України. 2010. - № 92 (10.12.2010) (Ч. 1). - Ст. 3248.

22. Aires v. Portugal (dec.), no. 21775/93, D.R. no. 81-B, p. 48.

23. Perdigao v. Portugal, no. 24768/06, § 41, 16 November 2010.

24. Курс цивільного процесу : підручник / В. В. Комаров, В. А. Бігун, В. В. Баранкова та ін. ; за ред. В. В. Комарова. - Харків : Право, 2011. - 1352 с.

\section{References:}

1. Pro derzhavne myto : Dekret Kabinetu Ministriv Ukrayiny vid 21.01.1993 r. № 7-93 // Vidom. Verkhov. Rady Ukrayiny. - 1993. - № 13 (30.03.1993). - St. 113.

2. Pro sudovyy zbir : Zakon Ukrayiny vid 08.07.2011 r. № 3674-VI // Ofitsiynyy visnyk Ukrayiny. - 2011. - № 59 (12.08.2011). - St. 2349.

3. Sovetskiy grazhdanskiy protsess : uchebnik / pod red. K. I. Komissarova i V. M. Semenova. 2-e izd., pererab i dop. - Moskva : Yurid. lit. - 480 s.

4. Grazhdanskoe protsessualnoe pravo Rossii : uchebnik dlya vuzov / pod red. M. S. Shakaryan. - Moskva : Yurist', 2002. - 634 s.

5. Tsyvil'nyy protsesual'nyy kodeks Ukrayiny :naukovo-praktychnyy komentar / za red. V. V. Komarova. - Kharkiv : Odissey, 2001. - 816 s. 
6. Shokueva, E. M. Institut sudebnyih rashodov v rossiyskom grazhdanskom sudoproizvodstve : avtoref. dis. ... kand. yurid. nauk : 12.00.15 / E. M. Shokueva. - Saratov. gos. akad. prava. - Saratov, 2005. - 27 s.7.

7. Bohlya S. S. Sudovi vtraty u tsyvil'nomu sudochynstvi : avtoref. dys. ... kand. yuryd. nauk : 12.00.03 / S. S. Bohlya ; Nats. un-t vnutr. sprav MVS Ukrayiny - Kharkiv, 2005. - 21 s.

8. Sovetskiy grazhdanskiy protsess / pod red. prof. M. K. Treushnikova. - Moskva : Izd-vo Mosk. un-ta, 1989. - $463 \mathrm{~s}$.

9. Grazhdanskiy protsess : uchebnik / otv. red. prof. V. V. Yarkov. - 5-e izd., pererab. i dop. Moskva : Volters Kluver, 2004. - 720 s.

10. Bespalov, Yu. F. Sudebnyie rashodyi po grazhdanskim, ugolovnyim delam i delam ob administrativnyih pravonarusheniyah : ucheb.-prakt. posobie / Yu. F. Bespalov, A. Yu. Bespalov. - Moskva : Prospekt, 2014. - 216 s.

11. Simaytis, R. Funktsii grazhdansko-protsessualnogo instituta sudebnyih rashodov / Rimantas Simaytis // Grazhdanskiy protsess: nauka i prepodavanie / pod red. M. K. Treshnikova, E. A. Borisovoy. - Moskva : Izd. Dom «Gorodets», 2005. - S. 302-313.

12. Pro zabezpechennya prava na spravedlyvyy sud : Zakon Ukrayiny vid 12.02 .2015 r. № 192VIII // Ofitsiynyy visnyk Ukrayiny. - 2015. - № 17 (10.03.2015). - St. 447.

13. Byudzhetnyy kodeks Ukrayiny vid 08.07.2010 r. № 2456-VI // Ofitsiynyy visnyk Ukrayiny. 2010. - № 59. - St. 2047.

14. Pro zastosuvannya sudamy zakonodavstva pro sudovi vytraty u tsyvil'nykh spravakh [Elektronnyy resurs] : postanova Plenumu Vyshchoho spetsializovanoho sudu Ukrayiny z rozhlyadu tsyvil'nykh i kryminal'nykh sprav vid 17.10.2014 r. № 10. - Rezhym dostupu : http://zakon4.rada.gov. ua/laws/show/v0010740-14.

15. Pro vnesennya zmin do deyakykh zakonodavchykh aktiv Ukrayiny shchodo profesiynoyi i trudovoyi reabilitatsiyi invalidiv : Zakon Ukrayiny vid 06.10.2005 r. № 2960- IV // Ofitsiynyy visnyk Ukrayiny. - 2005. - № 50 (28.12.2005) - St. 3108.

16. Zvarych, O. V. Instytutsiyni zasady sudovoho zboru i derzhavnoho myta / O. V. Zvarych // Visnyk Akademiyi mytnoyi sluzhby Ukrayiny. Seriya «Ekonomika» / Akad. mytnoyi sluzhby Ukrayiny. - Dnipropetr. : Akad. mytnoyi sluzhby Ukrayiny, 2013. - № 2 (50). - S. 5-10.

17. Lazyuk, S. V. Sudovyy zbir yak riznovyd derzhavnoho myta / S. V. Lazyuk // Pravo i suspil'stvo. - 2012. - № 6. - S. 63-65.

18. Kuybida, R. O. Reformuvannya pravosuddya v Ukrayini: stan i perspektyvy : monohrafiya / R. O. Kuybida. - Kyyiv : Atika, 2004. - 288 s.

19. Pro Kontseptsiyu vdoskonalennya sudivnytstva dlya utverdzhennya spravedlyvoho sudu v Ukrayini vidpovidno do yevropeys'kykh standartiv : Ukaz Prezydenta vid 10.05.2006 r. № 361/2006 // Ofitsiynyy visnyk Ukrayiny. - 2006. - № 19. - St. 1376.

20. Sakara, N. Yu. Problema dostupnosti pravosuddya u tsyvil'nykh spravakh : monohrafiya / N. Yu. Sakara. - Kharkiv : Pravo, 2010. - 256 s.

21. Podatkovyy kodeks Ukrayiny vid 02.12 .2010 r. № 2755-VI // Ofitsiynyy visnyk Ukrayiny. 2010. - № 92 (10.12.2010) (Ch. 1). - St. 3248.

22. Aires v. Portugal (dec.), no. 21775/93, D.R. no. 81-B, p. 48.

23. Perdigao v. Portugal, no. 24768/06, § 41, 16 November 2010.

24. Kurs tsyvil'noho protsesu : pidruchnyk / V. V. Komarov, V. A. Bihun, V. V. Barankova ta in. ; za red. V. V. Komarova. - Kharkiv : Pravo, 2011. - 1352 s.

Sakara N. Y., Candidate of Legal Sciences, Docent of civil procedure department of Yaroslav Mudryi National Law University, Kharkov, Ukraine.

e-mail: Natalija_sakara@mail.ru

Court fee legal nature

In the article the author attempts to determine court fee legal nature He comes from that court fee is included in the composition of court costs. Consequently these concepts are correlated as part 
and unit. Thus part adopts signs characteristic from unit, saving the feature. Court costs are statutory expenses (monetary resources) of parties, other persons participating in the case, born by them in connection with it consideration and permission, and in case of their exemption are expenses of the state that it carries in connection with permission of certain case. They perform two functions: compensation to the participants of process their expenses related to consideration of the case, and stopping from illegal and unconscientious judicial behavior.

The author comes from that court fee is not the type of state duty, as these payments have different purviews. Court fee is paid only at an appeal to the court, and state duties - to another unjudicial organs. In addition, in the national legislation since 1 January 2006 both payments are examined as national taxes and collections.

Legal nature of court fee it is suggested to determine taking into account those functions that it executes. Firstly, due to court fee the special fund of the state budget is filled up. Its facilities go to financing the functioning of the judicial system. A person, paying it, executes his public obligation. Secondly, the payment of court fee prevents illegal judicial behavior, stimulates parties to the extra-judicial settlement of dispute. Paying court fee a person discharges duties, envisaged by a procedural legislation.

It is suggested to understand court fee as a payment to the budget that is realized for specific public and procedural obligations fulfillment due to person's realization of his access to court for the legal defense right or due to person's court decree according to Law of Ukraine "About Court fee", the payment of which should entail some legally significant actions on this person as a receipt of "special benefit". The last mentioned should appear during writ, application, claim examination and appropriate court decision taking by results, that is in judicature for the purpose of person's rights, interests and freedoms protection.

Keywords: court costs; state duty; court fee; functions of court fee; public obligation; procedural obligation.

Надійшла до редколегї 25.02.2016 p. 